\title{
ANALYSIS OF RC BRIDGE DECKS FOR SELECTED NATIONAL AND INTERNATIONALSTANDARD LOADINGS USING FINITE ELEMENT \\ METHOD
}

Hemalatha $\mathrm{A}^{\mathbf{1}}$, Ashwin K. $\mathbf{N}^{\mathbf{2}}$, Dattatreya J.K ${ }^{\mathbf{3}}$, S.V.Dinesh ${ }^{4}$

${ }^{1}$ Post graduate Student, ${ }^{2}$ Assistant Professor, ${ }^{3}$ Research Professor, ${ }^{4}$ Professor and Head, Department of Civil Engineering, Siddaganga Institute of Technology, Tumkur.

hemacivil10@gmail.com,meetashwinkn@yahoo.com,jk.dattatreya@gmail.com,dineshsv2004@yahoo.com

\section{Abstract}

The paper presents the comparison of the effect of different standard loadings on a set of reinforced concrete bridge decks using the finite-element method. The parameters investigated include the aspect ratio (span/width) and type of loading. The investigations are conducted on two lane slab bridge decks of span $5 \mathrm{~m}$ to $9.5 \mathrm{~m}$ and two lane T beam bridge decks of span $7.5 \mathrm{~m}$ to $20 \mathrm{~m}$. A total of 36 bridge models were analyzed. The variation of different critical structur al response parameters such as deflection, longindinal bending moment, transverse moment, shear force and torsional moments are evaluated for IRC loading (IRC Class A and 70R loadings), AASHTO loading (HL93) and Euro standard loading (LMI). The results shows that the maximum difference in deflection and longitudinal bending moment for the two IRC standard loading ranges from 5 to $15 \%$. While the difference between corresponding values for the AASH A loading in the range of 5 to hes higher than IRC class A loading maximum axle load hence the values of structural response parameters are increased by 1.7 to 1.8 times. Therefore there is a need for adopting simplified and more realistic standard loads in the future.

Keywords: Bridges, Concrete deck slabs; Finite element method; T-beam bridge decks; Aspect ratio; Live load, IRC code AASHTO code and Euro code.

\section{INTRODUCTION}

Vehicular loads constitute the most important type of loading to be considered in the design of bridges. Many countries have formulated their own standard specification and codes of practice for bridges such as IRC, AASHTO and EURO codes, with a view to establish a common procedure for the design and construction of bridges. Most of the prevailing standar loads including the IRC bridge loads have very little ration basis and lacking relevance to the current vehicula configuration plying on the roads and bridges. With growing tendency to overload the vehicle beyond the permitted lega axle load and also increase in vehicular trafic, it has become IRC to evaluate the safety of existing bridges and for the design of many new brides for increased magnitude of loats and intensity of traffic. Reappraisal of the safety of existing bridges and design of new bridges is rather difficult in the Indian context due to complicated load pattern of differen classes of load therefore there is a need to simplify the loading standards and adopt more realistic design vehicle in similar to that adopted by AASHTO and EURO code. Also the loading standards depends on different factors such as type of vehic/e plying, their loading capacities, the intensity and frequency of traffic and logistic considerations for general mobilization in case of national emergencies. They may also have a bearing the country concestresses in materials and design methods not be viewed as strictly quantitative, it will be mor reasonable to take them as reflecting the global trend of the global effects of the loadings on the bridge.

Earlier investigation on comparative study of highway bridge loadings in different countries by Thomas(1975) concluded that there was a wide variation in the highway bridge loading standards of different countries and also Medhat Kamal Abdullah(2013) studied a comparison between different loading standards such as AASHTO, Egyptian and Euro code loadings and concluded that Egypt and Euro code loading were much higher than the AASHTO loadings. Also earlie analytical studies on bridges shows that modeling of bridges using FEM is easy and it gives accurate values, some of the studies are Maher Qaqish et al. (2008) found that the results Kanchan Sen Gupta et al(2011) caried out a investigations on Simply supported concrete bridge deck slab for IRC vehicle loadings using finite element analysis Reduction factors will be suggested to apply to the FEM 
bending moment results to get the results similar to IRC bending moments. Critical appraisal of literature shows that most of the studies on comparison of loadings have adopted simplified method such as grillage analysis and considered only simple deck bridges which are amenable to han computation. Since analytical modeling using FEM give complete picture of the bridge deck response. Therefore the comparisons of the effect of different standard loadings on set of reinforced concrete bridge decks using the finiteare found underestimated for those modifications are needed.

\section{PARAMETRIC STUDY}

Two types of bridge decks are considered for the analysis.

A typical simply supported, single span, two lane
slab bridge decks of span $5 \mathrm{~m}, 7.5 \mathrm{~m}$ and $9.5 \mathrm{~m}$ with constant slab depth of $0.75 \mathrm{~m}$

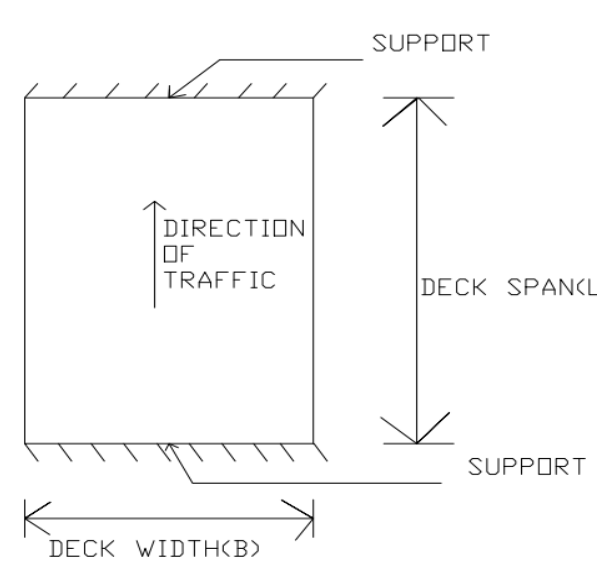

Fig.1.Description of Deck slab bridge.

\section{LOAD ON BRIDGE DECK MODELS}

In order to obtain the maximum structural response for the design, different positions of each type of loading system as per IRC 6:2000, AASHTO LRFD design specification an Euro code part 2 are analyzed. For the present study IRC clas 6:2000. HL 93 loadings are selected by seeing table 2 of IRC 1(LM1) from EURO code are considered.

\section{FINITE ELEMENT MODELLING}

The bridge decks are analyzed using Finite element method. The 4 nodded flat plate elements are used to model the
concrete slabs and the 2 nodded beam elements are used to model the concrete longitudinal beams and ends diaphragms. The mesh size of plate element is $0.2 \mathrm{~m} \times 0.2 \mathrm{~m}$. The material property of the concrete considered are the compressive ii. A typical simply supported, single span, two lane $\mathrm{T}$ beam bridge decks of span $7.5 \mathrm{~m}$ to $20 \mathrm{~m}$ at equal intervals of $2.5 \mathrm{mwith}$ constant slab depth of $0.3 \mathrm{~m}$ and beam dimension $0.4 \mathrm{~m} \times 1.6 \mathrm{~m}$.

The width of each bridge deck is $9.5 \mathrm{~m}$ in all cases and i includes $1 \mathrm{~m}$ footpath on both side of carriageway. Each $\mathrm{T}$ beam bridge decks consist of three longit two diaphragms at ends. The geometric configuration of slab bridge deck and $\mathrm{T}$ beam bridge deck are indicated in Fig.1 and

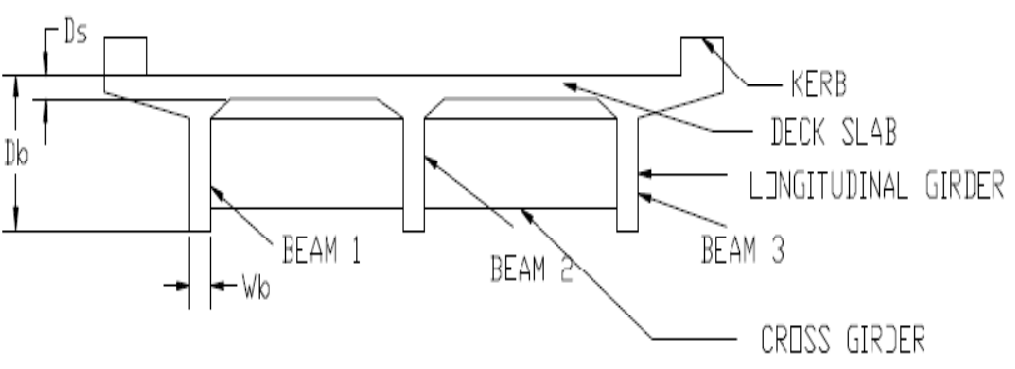

Fig.2.Description of $\mathrm{T}$ beams bridge deck.

strength $\left(\mathrm{f}_{\mathrm{ck}}{ }^{\prime}\right)=25 \mathrm{Mpa}$, the modules of elasticity $(\mathrm{E})=25$ $\mathrm{Gpa}$, the Poisson's ratio $(v)=0.2$ and density $=25 \mathrm{kN} / \mathrm{m}^{3}$.

5. RESULTS AND DISCUSSIONS

The following observations are made on the basis of the finite element analysis carried out and the results are represented in element analysis carried out and
the following charts and tables.

5.1 Variation of Important Structural Response Parameters in Slab Bridge Decks under Selected

\section{Loadings}

(A) Deflection:

It is seen from Fig.7a.thatthe maximum deflection value caused by IRC class A and IRC 70R wheeled vehicle do not differ by more than $7 \%$ for the selected aspect ratios of Slab 
Bridge decks investigated. Although the total axle load is less for IRC 70R compared to class A loading, closer wheel and axle spacing counteract the effect of decreased axle load and thereby induce the almost same order of deflection. For similar cases the deflection produced by AASHTO vehicle HL 93 is varying from -7 to $17 \%$ more than that of IRC class A
loading, although the total load of AASHTO vehicle exceeds

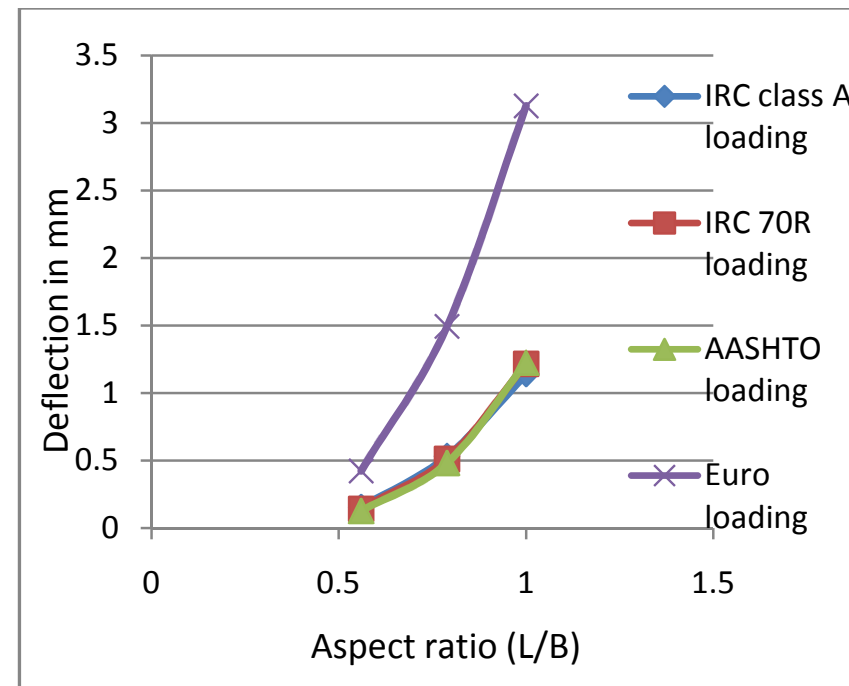

a. Variation of deflection.
$26 \%$ of IRC class A. In case of EURO standard vehicle LM1 there is a substantial increase in deflection from 1.7 to 1.8 times that of due to IRC class A against the maximum wheel load increase of 2.2. For the given class of loading the
deflection has increased approximate in proportion to the cube of the span in all cases.

Fig.7.Variation of maximum Deflection and longitudinal bending moment in Slab Bridge decks under selected loadings.

\section{(B) Longitudinal Bending Moment}

It is seen from Fig.7b. that the maximum bending moment values caused by IRC class A, IRC 70R and AASHTO vehicle do not differ by more than $5 \%$ which is much less than that of deflection for the selected aspect ratios of the slab bridge deflection, the change in bending moment will be a fraction of change in deflection. The order of increase in bending moment is similar to that of change in deflection. But the maximu longitudinal bending moment caused by EURO loading is more than 1.71 to 1.77 times that of due to IRC class A agains the maximum wheel load increase of 2.2 .

\section{(C) Transverse Bending Moment and Torsiona}

\section{Moment}

It is seen from Fig.8. that the transverse moments an torsional moments show considerable difference for differe standard loads and the order of difference ranges from 26 to $46 \%$ for IRC class $70 \mathrm{R}$ compared to IRC class $\mathrm{A}$ in case of

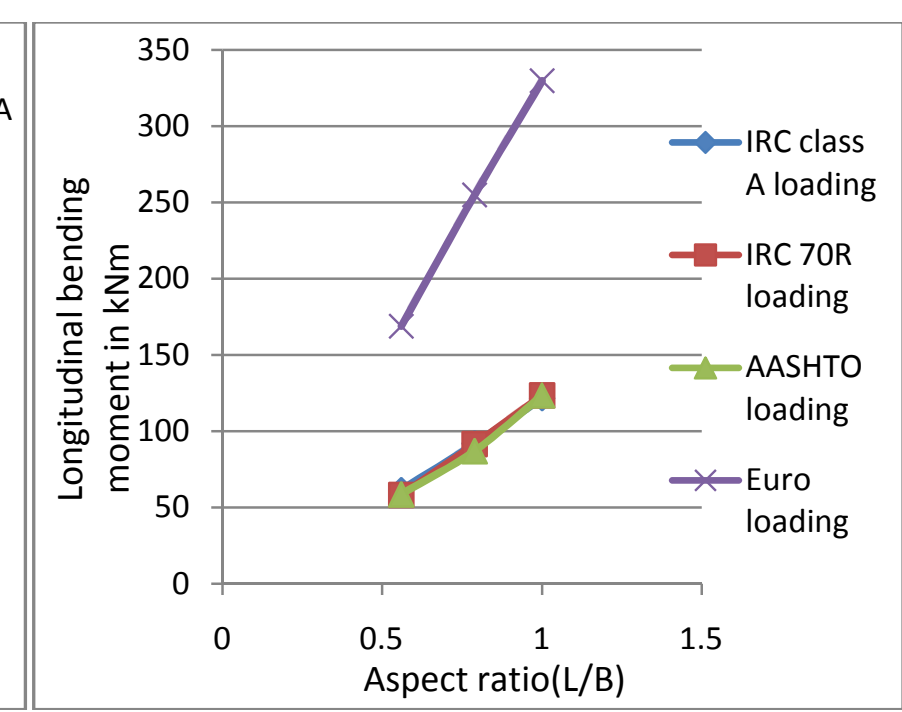

b. Variation of longitudinal bending moment.

moments. This is attributed to the considerable difference in wheel spacing and vehicle spacing, for example the spacing between two adjacent IRC class A loading is $1.8 \mathrm{mwhere}$ as the spacing between two inC $70 \mathrm{R}$ load is $0.79 \mathrm{~m}$. However the transverse moment and respectively of cones from the additionl longitudinal moment computed from the torsional moment is about 50 to $55 \%$ of the value of the latter. Therefore in view of considerable width of slab and its thickness the torsional and transverse moment cannot produce any significant distortion of deck and they get further reduced more than $50 \%$ of their original value on cracking during service load stage. The AASHTO load shows a result almost similar to IRC class A in respect of transverse moment but slightly higher increase of 29 to $31 \%$ in torsional moment due to difference in wheel configuration. The EURO standard load results in enhancement in magnitude of transverse an torsional moments in the range of 1.98 to 2.10 and 1.54 to 2.02 times respectively compared to that of IRC class A loading, mainly due to the wheel configuration changes. 


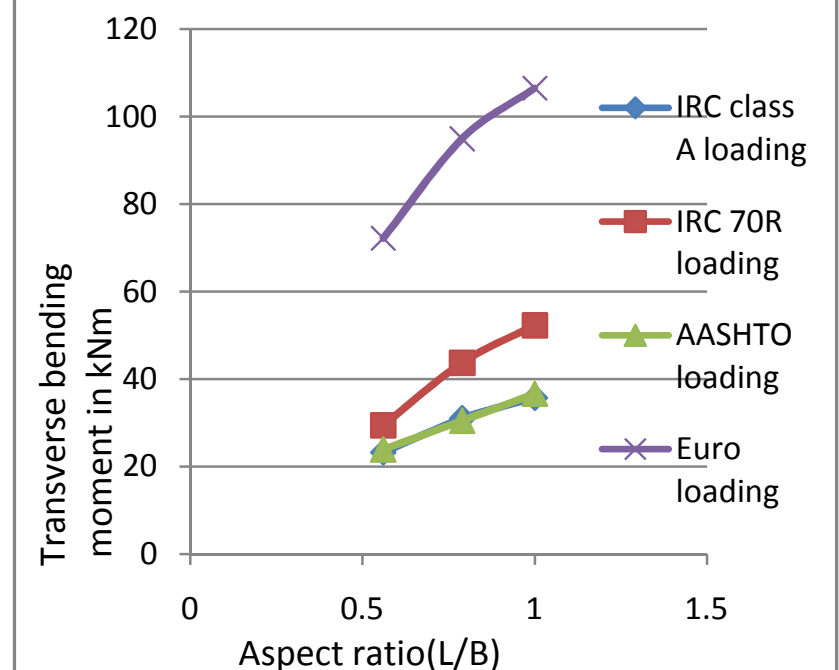

a. Variation of transverse bending moment.

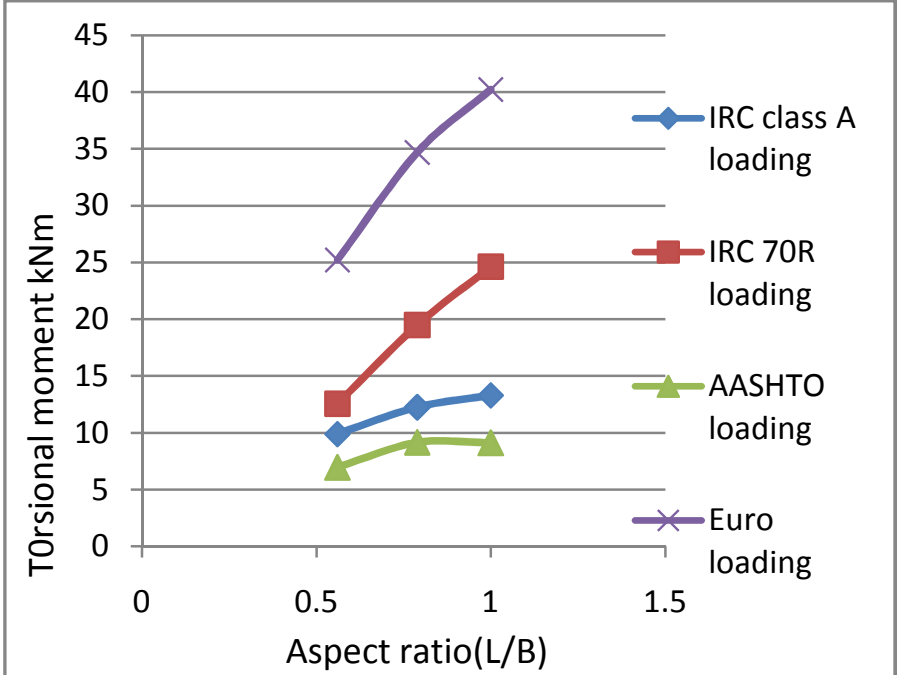

b. Variation of torsional moment.

Fig.8.Variation of maximum Transverse moment and maximum Torsional moments in deck slab bridges under selected loadings.

4.2 Variation of Important Structural Response Parameters in $\mathbf{T}$ Beam Bridge Deck Slabs under

\section{Selected Loadings}

It is seen from Fig.10. that the effect of standard loading on T beam bridge deck slab is found to follow a pattern similar to that slab bridge decks in respect of deflection, longitudinal moment with a difference of -3 to $11 \%$ in deflection, -29 to -

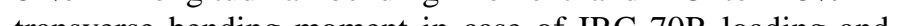
with a difference of -14 to $-44 \%$ in defletion, 19 to $-25 \%$ in
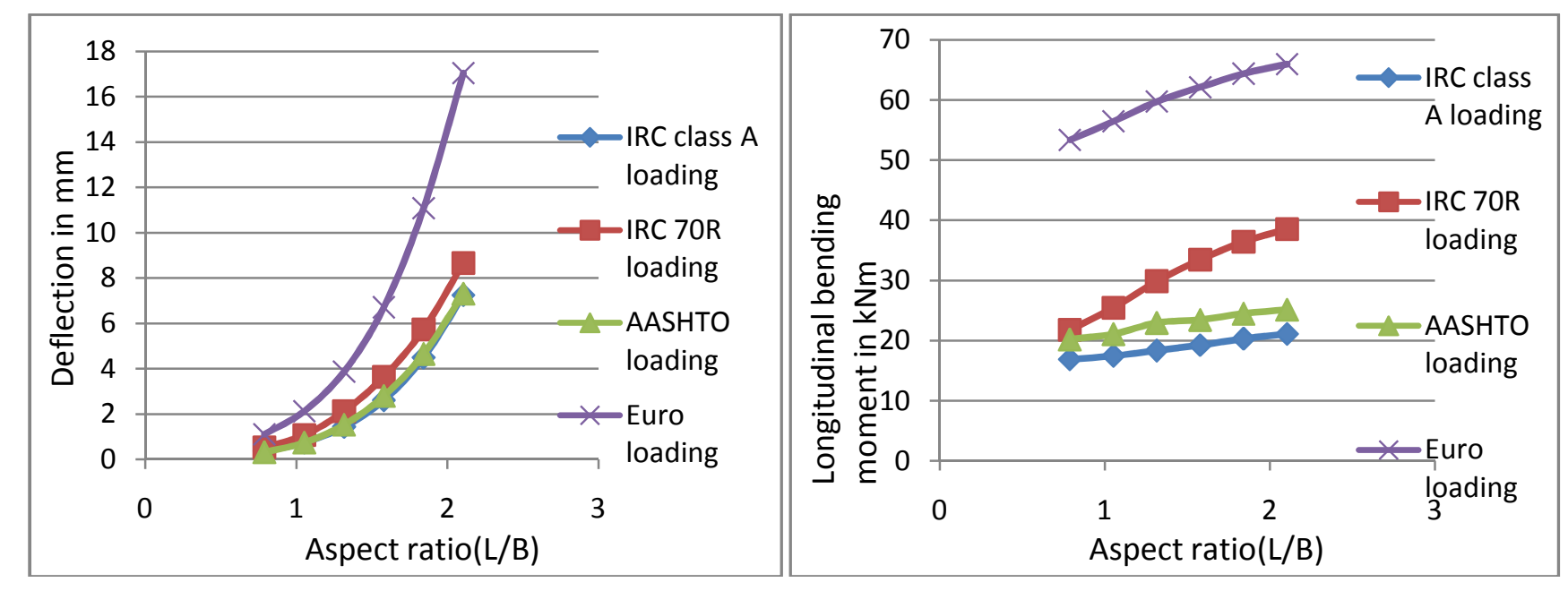

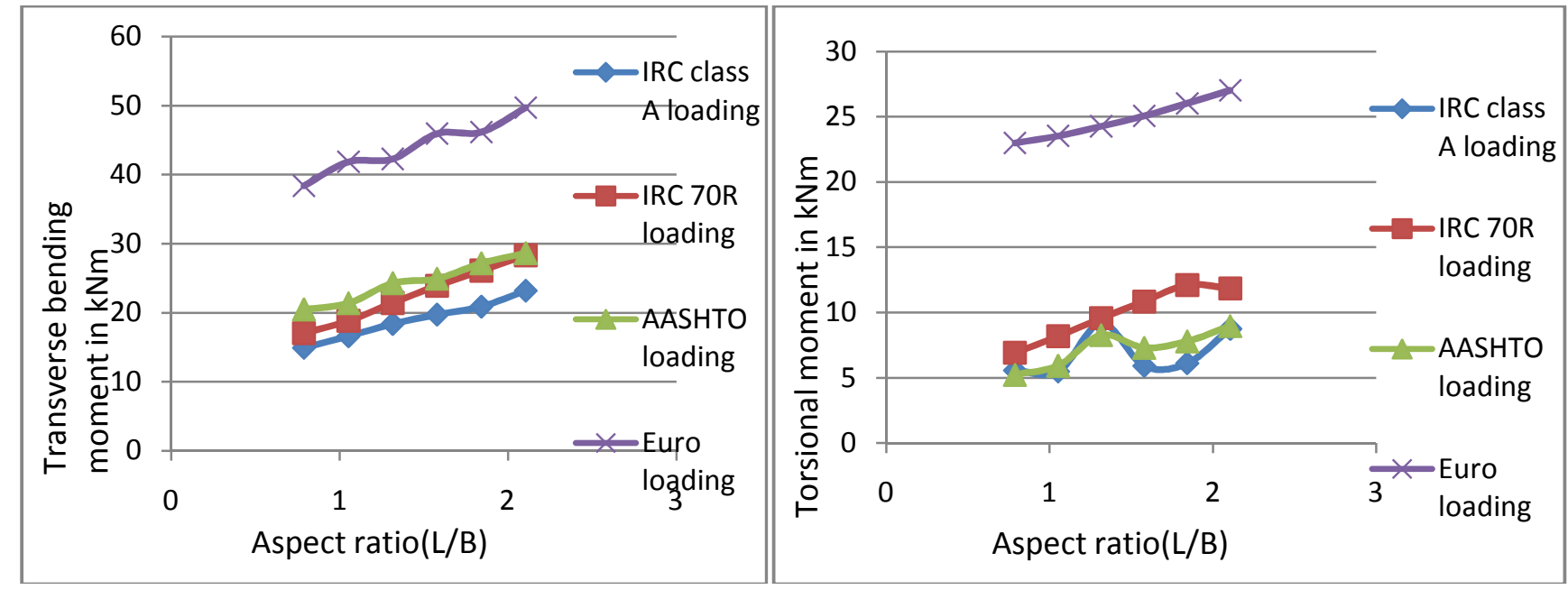

Fig.10.Variation of maximum Deflection, maximum longitudinal moment, maximum Transverse moment and maximum Torsiona moments in deck slab of $\mathrm{T}$ beam bridges under selected loadings.

4.3 Variation of Important Structural Response Parameters in the Longitudinal Girders of $T$ Beam Bridge Deck under Selected Loading:-

The variation of maximum deflection, maximum shear force, maximum longitudinal bending moment and maximum torsional monets in the longitudinal girders of T beam bridge decks are tabulated in the following tables 1 to 4 . The effect of standard loading on $\mathrm{T}$ beam bridge decks is found to follow a pattern similar to hat slab bidge decks in respect of $37 \%$ in deflection 10 to $-27 \%$ in moment in case IRC 70R loading. The coresoding differences in case of AASHTO loading are 8 to $-22 \%$ in deflection and -4 to $-15 \%$ in longitudinal bending moment is seen that the order of increase in maximum moment. deflection, longitudinal bending moment and transverse bending moment of $\mathrm{T}$ beam bridge decks due to Euro standard loading is about 1.07 to 1.9 times that of IRC class A loading. In case of torsional moment the increase is highest for IRC 70R loading compared to the class A primarily due to closed wheel spacing in the transverse direction. The variation in torsional moment is much less compared to a slab deck because the presence of girders in both direction and also reduce the distortion and warping caused by torsion. The maximum shear force in beams mainly depends on the magnitude of loading, since wheel load of AASHTO loading, Euro loading is more compared to IRC class A, the maximum shear force values produced by AASHTO loading, Euro respectively compared to that of IRC .5 to 1.8 thes Although the IRC class 70R wheel load is small compared to IRC class $A$ wheel load due to the closed wheel spacing the maximum shear force values decreased by -1 to $91 \%$. 
Table.1. Variation of Deflection in longitudinal girders

\begin{tabular}{|c|c|c|c|c|c|c|c|c|c|c|c|c|}
\hline \multirow{2}{*}{$\begin{array}{l}\text { Aspec } \\
\text { t ratio } \\
\text { (L/B) }\end{array}$} & \multicolumn{4}{|c|}{ Deflection in beam 1 in $\mathrm{mm}$} & \multicolumn{4}{|c|}{ Deflection in beam 2 in $\mathrm{mm}$} & \multicolumn{4}{|c|}{ Deflection in beam 3 in $\mathrm{mm}$} \\
\hline & $\begin{array}{l}\text { IRC } \\
\text { class A } \\
\text { loadin } \\
\mathrm{g}\end{array}$ & $\begin{array}{l}\text { IRC } \\
70 \mathrm{R} \\
\text { loadin } \\
\mathrm{g}\end{array}$ & $\begin{array}{l}\text { AASHT } \\
\text { O } \\
\text { loading }\end{array}$ & $\begin{array}{l}\text { Euro } \\
\text { loadin } \\
\mathrm{g}\end{array}$ & $\begin{array}{l}\text { IRC } \\
\text { class A } \\
\text { loadin } \\
\text { g }\end{array}$ & $\begin{array}{l}\text { IRC } \\
70 \mathrm{R} \\
\text { loadin } \\
\mathrm{g}\end{array}$ & $\begin{array}{l}\text { AASHT } \\
\text { O } \\
\text { loading }\end{array}$ & $\begin{array}{l}\text { Euro } \\
\text { loadin } \\
\mathrm{g}\end{array}$ & $\begin{array}{l}\text { IRC } \\
\text { class A } \\
\text { loadin } \\
\mathrm{g}\end{array}$ & $\begin{array}{l}\text { IRC } \\
70 \mathrm{R} \\
\text { loadin } \\
\mathrm{g}\end{array}$ & $\begin{array}{l}\text { AASHT } \\
\text { O } \\
\text { loading }\end{array}$ & $\begin{array}{l}\text { Euro } \\
\text { loading }\end{array}$ \\
\hline 0.789 & 0.252 & 0.237 & 0.221 & 0.744 & 0.273 & 0.321 & 0.249 & 0.701 & 0.124 & 0.026 & 0.16 & 0.231 \\
\hline 1.053 & 0.614 & 0.697 & 0.643 & 1.793 & 0.628 & 0.83 & 0.7 & 1.596 & 0.325 & 0.138 & 0.478 & 0.629 \\
\hline 1.316 & 1.34 & 1.666 & 1.41 & 3.588 & 1.293 & 1.771 & 1.469 & 3.046 & 0.755 & 0.469 & 1.076 & 1.415 \\
\hline 1.579 & 2.492 & 3.228 & 2.695 & 6.354 & 2.263 & 3.113 & 2.706 & 5.233 & 1.496 & 1.138 & 2.112 & 2.784 \\
\hline 1.842 & 4.276 & 5.455 & 4.594 & 10.309 & 3.68 & 4.962 & 4.498 & 8.371 & 2.705 & 2.253 & 3.686 & 4.953 \\
\hline 2.105 & 6.862 & 8.555 & 7.241 & 15.704 & 6.116 & 7.496 & 6.979 & 12.706 & 4.568 & 3.989 & 5.94 & 8.169 \\
\hline
\end{tabular}

Table.2. Variation of Shear force in longitudinal girders

\begin{tabular}{|c|c|c|c|c|c|c|c|c|c|c|c|c|}
\hline \multirow{2}{*}{$\begin{array}{l}\text { Aspec } \\
\text { t ratio } \\
\text { (L/B) }\end{array}$} & \multicolumn{4}{|c|}{ Shear force in beam $1 \mathrm{in} \mathrm{kN}$} & \multicolumn{4}{|c|}{ Shear force in beam 2 in $\mathrm{kN}$} & \multicolumn{4}{|c|}{ Shear force in beam 3 in $\mathrm{kN}$} \\
\hline & $\begin{array}{l}\text { IRC } \\
\text { class A } \\
\text { loading }\end{array}$ & $\begin{array}{l}\text { IRC } \\
70 \mathrm{R} \\
\text { loading }\end{array}$ & $\begin{array}{l}\text { AASHT } \\
\text { O } \\
\text { loading }\end{array}$ & $\begin{array}{l}\text { Euro } \\
\text { loading }\end{array}$ & $\begin{array}{l}\text { IRC } \\
\text { class A } \\
\text { loading }\end{array}$ & $\begin{array}{l}\text { IRC } \\
70 \mathrm{R} \\
\text { loading }\end{array}$ & $\begin{array}{l}\text { AASHT } \\
\text { O } \\
\text { loading }\end{array}$ & $\begin{array}{l}\text { Euro } \\
\text { loading }\end{array}$ & $\begin{array}{l}\text { IRC } \\
\text { class A } \\
\text { loading }\end{array}$ & $\begin{array}{l}\text { IRC } \\
70 R \\
\text { loadin } \\
\text { g }\end{array}$ & $\begin{array}{l}\text { AASHT } \\
\text { O } \\
\text { loading }\end{array}$ & $\begin{array}{l}\text { Euro } \\
\text { loading }\end{array}$ \\
\hline 0.789 & $\begin{array}{c}121.83 \\
8 \\
\end{array}$ & 94.266 & 115.712 & $\begin{array}{r}329.13 \\
5 \\
\end{array}$ & $\begin{array}{c}123.67 \\
9 \\
\end{array}$ & $\begin{array}{c}150.81 \\
2 \\
\end{array}$ & 112.027 & $\begin{array}{r}293.74 \\
7 \\
\end{array}$ & 48.191 & 4.611 & 71.333 & 82.902 \\
\hline 1.053 & $\begin{array}{c}107.10 \\
6\end{array}$ & $\begin{array}{c}129.42 \\
1\end{array}$ & 140.832 & $\begin{array}{r}368.98 \\
5 \\
\end{array}$ & $\begin{array}{c}139.59 \\
7 \\
\end{array}$ & $\begin{array}{c}183.08 \\
9\end{array}$ & 141.789 & $\begin{array}{r}330.55 \\
1 \\
\end{array}$ & 59.694 & 14.844 & 92.389 & $\begin{array}{r}103.60 \\
9\end{array}$ \\
\hline 1.316 & $\begin{array}{c}146.50 \\
2 \\
\end{array}$ & $\begin{array}{c}167.38 \\
2 \\
\end{array}$ & 162.393 & 401.3 & 148.76 & $\begin{array}{c}187.02 \\
2 \\
\end{array}$ & 165.473 & 356.95 & 68.497 & 30.78 & 112.691 & $\begin{array}{r}123.04 \\
5 \\
\end{array}$ \\
\hline 1.579 & $\begin{array}{c}153.42 \\
4 \\
\end{array}$ & $\begin{array}{c}196.13 \\
5 \\
\end{array}$ & 180.23 & $\begin{array}{r}430.22 \\
5 \\
\end{array}$ & $\begin{array}{c}154.78 \\
6 \\
\end{array}$ & $\begin{array}{c}229.52 \\
2 \\
\end{array}$ & 183.004 & $\begin{array}{r}379.40 \\
9 \\
\end{array}$ & 75.37 & 48.028 & 129.336 & $\begin{array}{r}142.03 \\
2 \\
\end{array}$ \\
\hline 1.842 & $\begin{array}{c}166.69 \\
4 \\
\end{array}$ & $\begin{array}{c}221.04 \\
4 \\
\end{array}$ & 195.759 & $\begin{array}{r}457.36 \\
5 \\
\end{array}$ & 168.56 & $\begin{array}{c}228.15 \\
7 \\
\end{array}$ & 197.896 & $\begin{array}{r}399.51 \\
1 \\
\end{array}$ & $\begin{array}{c}104.17 \\
8 \\
\end{array}$ & 64.442 & 143.938 & 160.95 \\
\hline 2.105 & $\begin{array}{c}183.97 \\
4 \\
\end{array}$ & 238.93 & 209.758 & 482.33 & $\begin{array}{c}185.25 \\
9\end{array}$ & $\begin{array}{c}256.69 \\
8\end{array}$ & 210.86 & $\begin{array}{r}418.15 \\
7 \\
\end{array}$ & $\begin{array}{c}118.74 \\
1\end{array}$ & 80.034 & 156.747 & $\begin{array}{r}179.66 \\
2\end{array}$ \\
\hline
\end{tabular}

Table.3. Variation of Longitudinal bending moments in longitudinal girders

\begin{tabular}{|c|c|c|c|c|c|c|c|c|c|c|c|c|}
\hline \multirow{2}{*}{$\begin{array}{l}\text { Aspec } \\
\text { t ratio } \\
\text { (L/B) }\end{array}$} & \multicolumn{4}{|c|}{ Bending moment in beam 1 in $\mathrm{kNm}$} & \multicolumn{4}{|c|}{ Bending moment in beam 2 in $\mathrm{kNm}$} & \multicolumn{4}{|c|}{ Bending moment in beam 3 in $\mathrm{kNm}$} \\
\hline & $\begin{array}{l}\text { IRC } \\
\text { class } \\
\text { A } \\
\text { loadin } \\
\text { g }\end{array}$ & $\begin{array}{l}\text { IRC } \\
70 R \\
\text { loadin } \\
\mathrm{g} \\
\end{array}$ & $\begin{array}{l}\text { AASHT } \\
\text { O } \\
\text { loading }\end{array}$ & $\begin{array}{l}\text { Euro } \\
\text { loadin } \\
\mathrm{g}\end{array}$ & $\begin{array}{l}\text { IRC } \\
\text { class A } \\
\text { loadin } \\
\mathrm{g}\end{array}$ & $\begin{array}{l}\text { IRC } \\
70 R \\
\text { loadin } \\
\mathrm{g}\end{array}$ & $\begin{array}{l}\text { AASHT } \\
\text { O } \\
\text { loading }\end{array}$ & $\begin{array}{l}\text { Euro } \\
\text { loadin } \\
\mathrm{g}\end{array}$ & $\begin{array}{l}\text { IRC } \\
\text { class A } \\
\text { loading }\end{array}$ & $\begin{array}{l}\text { IRC } \\
70 R \\
\text { loadin } \\
\mathrm{g} \\
\end{array}$ & $\begin{array}{l}\text { AASHT } \\
\text { O } \\
\text { loading }\end{array}$ & $\begin{array}{l}\text { Euro } \\
\text { loadin } \\
\mathrm{g}\end{array}$ \\
\hline 0.789 & 269.87 & 241.21 & 222.69 & 787.6 & 292.89 & 324.44 & 246.99 & 748.36 & 133.09 & 25.97 & 159.80 & 243.09 \\
\hline
\end{tabular}


IJRET: International Journal of Research in Engineering and Technology eISSN: 2319-1163 | pISSN: 2321-7308

\begin{tabular}{|r|r|r|r|r|r|r|r|r|r|r|r|r|}
1.053 & 398.93 & 414.63 & 376.65 & 1152.9 & 412.69 & 502.45 & 408.59 & 1043.3 & 207.35 & 81.19 & 278.66 & 395.38 \\
\hline 1.316 & 567.53 & 660.40 & 560.5 & 1538.3 & 555.30 & 703.2 & 582.43 & 1334.7 & 314.22 & 181.83 & 425.25 & 587.18 \\
\hline 1.579 & 740.92 & 907.01 & 759.72 & 1937.2 & 697.97 & 882.12 & 762.67 & 1634.8 & 434.71 & 313.39 & 591.96 & 814.7 \\
\hline 1.842 & 937.49 & 1149.4 & 968.94 & 2345.6 & 860.91 & 1051.8 & 949.3 & 1952.5 & 580.65 & 462.56 & 772.57 & 1075 \\
\hline 2.105 & 1139.7 & 1399.5 & 1185.24 & 2761.5 & 1031.7 & 1237.1 & 1145.1 & 2290 & 738.29 & 633.36 & 965.59 & 1364.8 \\
\hline
\end{tabular}

Table.4. Variation of Torsional moments in longitudinal girders

\begin{tabular}{|c|c|c|c|c|c|c|c|c|c|c|c|c|}
\hline \multirow[b]{2}{*}{$\begin{array}{l}\text { Aspe } \\
\text { ct } \\
\text { ratio( } \\
\text { L/B) }\end{array}$} & \multicolumn{4}{|c|}{ Torsional moment in beam 1 in $\mathrm{kNm}$} & \multicolumn{4}{|c|}{ Torsional moment in beam 2 in $\mathrm{kNm}$} & \multicolumn{4}{|c|}{ Torsional moment in beam 3 in $\mathrm{kNm}$} \\
\hline & $\begin{array}{l}\text { IRC } \\
\text { class } \\
\text { A } \\
\text { loadin } \\
\mathrm{g} \\
\end{array}$ & $\begin{array}{l}\text { IRC } \\
70 \mathrm{R} \\
\text { loadin } \\
\mathrm{g}\end{array}$ & $\begin{array}{l}\text { AASHT } \\
\mathrm{O} \\
\text { loading }\end{array}$ & $\begin{array}{l}\text { Euro } \\
\text { loadin } \\
\mathrm{g}\end{array}$ & $\begin{array}{l}\text { IRC } \\
\text { class } \\
\text { A } \\
\text { loadin } \\
\text { g } \\
\end{array}$ & $\begin{array}{l}\text { IRC } \\
70 \mathrm{R} \\
\text { loadin } \\
\mathrm{g}\end{array}$ & $\begin{array}{l}\text { AASHT } \\
\text { O } \\
\text { loading }\end{array}$ & $\begin{array}{l}\text { Euro } \\
\text { loadin } \\
\mathrm{g}\end{array}$ & $\begin{array}{l}\text { IRC } \\
\text { class } \\
\text { A } \\
\text { loadin } \\
\mathrm{g} \\
\end{array}$ & $\begin{array}{l}\text { IRC } \\
70 \mathrm{R} \\
\text { loadin } \\
\mathrm{g}\end{array}$ & $\begin{array}{l}\text { AASHT } \\
\mathrm{O} \\
\text { loading }\end{array}$ & $\begin{array}{l}\text { Euro } \\
\text { loadin } \\
\mathrm{g}\end{array}$ \\
\hline 0.789 & 15.5 & 35.5 & 4.7 & 32.4 & 2.45 & 24.9 & 3.977 & 37.24 & 20.8 & 6.69 & 20.32 & 35.17 \\
\hline 1.053 & 14.6 & 42 & 6.25 & 31.78 & 3.45 & 29.3 & 3.361 & 43.28 & 25 & 18.4 & 25.18 & 45.3 \\
\hline 1.316 & 15.2 & 44.7 & 6.46 & 32.93 & 6.61 & 38 & 3.54 & 50.3 & 28.2 & 34.1 & 29.61 & 56.07 \\
\hline 1.579 & 15.9 & 41.4 & 5.75 & 38.7 & 10.6 & 46.5 & 5.59 & 57.8 & 30.4 & 48.6 & 32.8 & 67.8 \\
\hline 1.842 & 16.9 & 35.6 & 6.12 & 46.2 & 15.1 & 53.7 & 8.31 & 66.1 & 35.7 & 58.7 & 35.14 & 81 \\
\hline 2.105 & 22.6 & 32.3 & 6.492 & 56.9 & 19.8 & 64.2 & 11.07 & 76.6 & 40.7 & 74.9 & 37.37 & 94.8 \\
\hline
\end{tabular}

4.4 Comparison of important structural response parameters in selected slab bridge deck and $\mathbf{T}$ beam bridge deck slab of aspect ratio 0.789 under selected loading:-

The comparison of important structural parameters in slab bridge deck and $\mathrm{T}$ beam bridge deck slab of aspect ratio 0.789 is shown in the Table.9. The maximum deflection in $\mathrm{T}$ beam bridge deck slab is reduced by 25 to $30 \%$ in case of IRC class A, AASHTO and EURO loading compared to slab bridge deck but in case of IRC 70R loading maximum deflection increases by $1.95 \%$ because of less wheel spacing. In case of longitudinal bending moment in $\mathrm{T}$ beam bridge deck slab is decreased by 76 to $81 \%$ compared to slab bridge deck for all selected loading cases. Similarly the transverse bending moment and tosional moment in $\mathrm{T}$ beam bridge deck slab is reduced by 33 to $65 \%$ compared to slab bridge deck for all selected loading cases. This reduction in important structural parameters in $\mathrm{T}$ beam bridge deck slab compared to slab bridge deck is due to the provision beams in both direction of slab.

Table.5. Comparison of important structural response parameters in selected slab bridge deck and $\mathrm{T}$ beam bridge deck slab of aspect ratio 0.789 under selected loading

\begin{tabular}{|c|c|c|c|c|c|c|c|c|}
\hline Loading & \multicolumn{2}{|c|}{ IRC class A Loading } & \multicolumn{2}{|c|}{ IRC 70R Loading } & \multicolumn{2}{|c|}{ AASHTO Loading } & \multicolumn{2}{|c|}{ EURO Loading } \\
\hline Bridge deck type & $\begin{array}{l}\text { Slab } \\
\text { deck }\end{array}$ & $\begin{array}{l}\text { T beam } \\
\text { deck }\end{array}$ & $\begin{array}{l}\text { Slab } \\
\text { deck }\end{array}$ & $\begin{array}{l}\text { T beam } \\
\text { deck }\end{array}$ & $\begin{array}{l}\text { Slab } \\
\text { deck }\end{array}$ & $\begin{array}{l}\text { T beam } \\
\text { deck }\end{array}$ & $\begin{array}{l}\text { Slab } \\
\text { deck }\end{array}$ & $\begin{array}{l}\text { T beam } \\
\text { deck }\end{array}$ \\
\hline Deflection in mm & 0.533 & 0.361 & 0.513 & 0.523 & 0.483 & 0.319 & 1.493 & 1.105 \\
\hline $\begin{array}{l}\text { Longitudinal bending } \\
\text { moment in } \mathrm{kNm}\end{array}$ & 91.94 & 16.874 & 91.472 & 21.788 & 87.114 & 20.199 & 254.868 & 53.372 \\
\hline $\begin{array}{l}\text { Transverse bending } \\
\text { moment in } \mathrm{kNm}\end{array}$ & 30.987 & 14.913 & 43.725 & 17.032 & 30.447 & 20.465 & 94.962 & 38.392 \\
\hline Torsion in $\mathrm{kNm}$ & 12.268 & 5.572 & 19.491 & 6.933 & 9.164 & 5.242 & 34.693 & 22.989 \\
\hline
\end{tabular}




\section{CONCLUSIONS}

a. The maximum values of deflection and longitudinal bending moment caused by IRC class $\mathrm{A}$ and $70 \mathrm{R}$ wheeled vehicle do not differ by more than $7 \%$ for the selected aspect ratios of Slab Bridge decks investigated.The corresponding difference in case of $\mathrm{T}$ beam decks is -22 to $37 \%$.

b. AASHTO loading causes -7 to $17 \%$ higher deflection and less than $5 \%$ in case of longitudinal bending moment compared to IRC class A loading. While the corresponding range is 1.7 to 1.8 times for EURO loading.

c. In general maximum transverse and maximum torsional moments are more pronounced in case of slab bridge decks compared to T beam decks and are found to be in the range of 15 to $20 \%$ and 30 to $40 \%$ respectively of corresponding longitudinal moment in case slab bridge decks and less than $5 \%$ of corresponding longitudinal moment in case of $\mathrm{T}$ beam decks because of higher transverse moment of inertia and torsional rigidity.

d. Because of their lower magnitude and thick solid sections are adopted for the members the maximum torsional moment and maximum transverse bending moments may not have any major significance on the design of slab bridge deck and T beam bridge deck.

e. The provision of $\mathrm{T}$ beam bridge decks instead of solid bridge decks of same aspect ratio is found to reduce in maximum deflection values by 25 to $30 \%$ and the maximum longitudinal bending moment values are reduced by 76 to $81 \%$. Another major advantage is the reduction in maximum torsional and maximum transverse moments by 33 to $65 \%$.

f. The study shows that there is a wide variation in the highway bridge loading standards of different countries. However the changes in critical response parameters are not very significant. IRC has adopted 6 standard loadings with widely varying magnitude of wheel loading and wheel and axle spacing. However the investigations indicate that there is no appreciable difference in structural response parameters for the different loadings. It is suggested that IRC may also adopt the single design vehicle with simple configuration for standard loading similar to AASHTO and EURO standard loading which have only 2 to 3 axles.

\section{REFERENCES}

[1] P.K. Thomas "A Comparative Study of Highway Bridge Loadings in Different Countries"supplementary report 135UC, Transport and road research laboratory.

[2] Medhat Kamal Abdullah "Comparison between Highway Codes for Traffic Loads on Bridges"Life Science Journal 2013: PP.621-627.

[3] Dr.MaherQaqish, Dr.EyadFaddaand Dr.EmadAkawwi“Design of T-beam Bridge by Finite
Element Method and AASHTO Specification"KMITL Sci. Journal. Vol.8 No.1 January - June, 2008.

[4] KanchanSen Gupta and SomnathKarmakar"Investigations on Simply supported concrete bridge deck slab for IRC vehicle loadings using finite element analysis"Journal of Earth Sciences and Engineering, Volume 04, No 06 SPL, October 2011, PP. 716-719.

[5] IRC 6:2000 "Standard Specifications and Code of Practice for Road Bridges, Section-II Loads and Stresses", Indian Road Congress, New Delhi.

[6] American Association of State and Highway Transportation Officials (AASHTO) specifications.

[7] Eurocode 1 Part 2 - prEN 1991-2-2002.

[8] IRC 21:2000 "Standard Specifications and Code of Practice for Road Bridges, Section-III Cement Concrete (Plain and Reinforced)",Indian Road Congress, New Delhi. 